\title{
Pengaruh Cahaya dan Suhu Berdasarkan Karakter Fotosintesis Ceratophyllum demersum sebagai Agen Fitoremediasi
}

\section{Effect of Light and Temperature Based on the Photosynthetic Characteristics of Ceratophyllum demersum as a Phytoremediation Agent}

\author{
Diana Lupitasari ${ }^{1}$, Melina Melina ${ }^{2}$, Valentina Adimurti Kusumaningtyas ${ }^{1, *}$ \\ ${ }^{1}$ Jurusan Kimia, Fakultas Sains dan Informatika, Universitas Jenderal Achmad Yani \\ Cimahi, Indonesia \\ ${ }^{2}$ Jurusan Informatika, Fakultas Sains dan Informatika, Universitas Jenderal Achmad Yani, Cimahi, Indonesia \\ *E-mail: valentina.adimurti@lecture.unjani.ac.id
}

DOI: https://doi.org/10.26874/jkk.v3i1.53

Received: 30 May 2020, Revised: 31 May 2020, Accepted: 31 May 2020, Online: 31 May 2020

\begin{abstract}
Abstrak
Oksigen yang kita hirup adalah hasil dari fotosintesis yang dilakukan oleh tumbuhan. Hampir semua makhluk hidup bergantung pada energi yang dihasilkan dalam fotosintesis. Tujuan dari penelitian ini adalah untuk menyelidiki kemampuan tanaman coontail (Ceratophyllum demersum) dalam menghasilkan gas oksigen yang digunakan untuk kelangsungan hidup biota air serta mengetahui pengaruh suhu dan intensitas cahaya matahari dalam proses fotosintesis. Metode yang digunakan dalam penelitian ini adalah metode Ingenhousz dengan tiga perlakuan berbeda yaitu ditempatkan pada ruangan terbuka, ruangan tertutup dan menggunakan air yang dipanaskan pada suhu $40{ }^{\circ} \mathrm{C}$. Jumlah gelembung oksigen dengan hasil terbanyak adalah pada perlakuan suhu $40{ }^{\circ} \mathrm{C}$ yaitu 30 buah gelembung dalam 40 menit. Tanaman coontail baik digunakan sebagai agen fitoremediasi karena tanaman ini memiliki kemampuan berfotosintesis yang cukup baik untuk menjaga kelangsungan hidup biota air.
\end{abstract}

Kata Kunci: fotosintesis, Ceratophyllum demersum, suhu, cahaya, Ingenhousz

\begin{abstract}
The purpose of this study is to investigate the ability of coontail plants (Ceratophyllum demersum) to produce oxygen gas which is used for the survival of aquatic biota and to determine the effect of temperature and intensity of sunlight in photosynthesis. The method used in this study is the Ingenhousz method with three sets of devices that are given different treatment that is placed in an open space, a closed room and using water that is heated at a temperature of $40^{\circ} \mathrm{C}$. The number of oxygen bubbles with the highest yield was at a treatment temperature of $40^{\circ} \mathrm{C}$, 30 bubbles in 40 minutes. Coontail plants are best used as phytoremediation agents because these plants have quite good photosynthetic abilities to maintain the survival of aquatic biota.
\end{abstract}

Keyword: photosynthesis, Ceratophyllum demersum, temperature, light, Ingenhousz

\section{Pendahuluan}

Sungai memiliki fungsi penting bagi kehidupan sebagai salah satu komponen lingkungan yaitu untuk menunjang keseimbangan lingkungan. Sebagai akibat adanya peningkatan kegiatan pembangunan di berbagai bidang, baik secara langsung maupun tidak langsung akan mempunyai dampak terhadap kerusakan lingkungan termasuk di dalamnya pencemaran sungai [1]. Berbagai macam polutan yang ada di sungai, baik yang berasal dari logam seperti kromium, timbal, kadmium, tembaga, seng dan nikel serta berasal dari senyawa organik yang berbahaya yaitu fenol [2-4]. Fenol dapat menyebabkan iritasi kulit, peradangan, degradasi protein, dan kelumpuhan sistem saraf pusat meski konsentrasinya rendah [5]. 
Organisme heterotrof yaitu organisme yang hidupnya bergantung pada organisme autotrof. Salah satunya adalah hewan. Dengan tercemarnya sungai maka keberadaan organisme tersebut akan terancam karena tidak memiliki kemampuan menghasilkan energi dari senyawa anorganik yaitu air dan karbon dioksida [6]. Dibutuhkan tumbuhan alternatif yang dapat bertahan dalam sungai, kolam atau danau yang tercemar, agar tetap menghasilkan oksigen bagi kehidupan biota air. Tumbuhan hijau memiliki sifat autotrof yakni mampu menghasilkan energi dan oksigen dengan memanfaatkan energi matahari untuk sintesis molekul-molekul organik kaya energi seperti glukosa. Tumbuhan hijau dalam menghasilkan suatu energi umumnya dalam bentuk Adenosine Triphosphate (ATP) bergantung pada proses fotosintesis [6]. Proses fotosintesis yang efektif dapat menghasilkan energi yang lebih besar dibandingkan energi yang terpakainya. Sebagian dari energi yang dihasilkan disimpan dalam bentuk cadangan makanan dan untuk pembentukan metabolit sekunder [7]. Beberapa faktor yang mempengaruhi laju fotosintesis yaitu cahaya, konsentrasi karbon dioksida, persediaan air, kandungan klorofil, penimbunan hasil fotosintesis, suhu, resistensi daun terhadap difusi gas bebas, dan faktor protoplasma.

Tumbuhan hijau alternatif yang digunakan dalam penelitian ini adalah tanaman coontail/racoon (Ceratophyllum demersum) yang diperoleh dari sungai. Tanaman ini mampu menyerap nitrat, amonia sama halnya dengan tumbuhan Cassia grandis yang mempunyai kemampuan memfiksasi nitrogen, sehingga mempunyai kemampuan menghasilkan berbagai senyawa metabolit sekunder [8], selain itu tanaman coontail ini pertumbuhannya cepat, sehingga sangat potensial untuk digunakan sebagai tanaman fitoremediasi. Metode yang digunakan dalam penelitian ini adalah metode penelitian Ingenhousz, kelebihan dari metode ini adalah digunakan untuk penelitian pada tumbuhan air, sederhana dan menggunakan biaya yang relatif murah.

Tujuan penelitian ini adalah untuk mengetahui kemampuan tanaman coontail $C$. demersum dalam menghasilkan gas oksigen yang digunakan untuk kelangsungan hidup hewan air sungai. Serta mengetahui pengaruh suhu dan cahaya matahari dalam proses fotosintesis.

\section{Metode Penelitian}

Penelitian ini dilakukan di Laboratorium Kimia Fakultas Sains dan Informatika Universitas Jenderal Achmad Yani.

\subsection{Alat dan Bahan}

Alat yang digunakan dalam penelitian ini adalah gelas kimia $500 \mathrm{~mL}$, corong gelas, tabung reaksi, kaki tiga, kasa asbes, pembakar spiritus dan termometer. Sedangkan bahan yang digunakan dalam penelitian ini adalah akuades dan tanaman coontail.

\subsection{Prosedur Penelitian}

Gelas kimia diisi air hingga $500 \mathrm{~mL}$ kemudian tumbuhan coontail dimasukkan ke dalam gelas kimia dan dibiarkan terapung dalam air. Corong gelas diletakkan dalam keadaan terbalik dan disangga dengan tiga kawat hingga corong gelas sedikit terangkat. Ujung corong gelas yang terbalik ditutup dengan tabung reaksi hingga tabung reaksi tersebut terisi air dengan penuh (Gambar 1). Penelitian ini dibuat tiga jenis perlakuan. Percobaan pertama diletakkan di tempat yang terkena cahaya matahari langsung. Percobaan kedua diletakkan di tempat yang tidak terkena cahaya matahari langsung. Sedangkan Percobaan ketiga air yang digunakan adalah air hangat. Setelah ketiga rangkaian dibentuk, diamati gelembung yang muncul kemudian dicatat hasilnya [6].

\section{$3 \quad$ Hasil dan Diskusi}

Tanaman coontail yang digunakan berasal dari Subang, Jawa Barat. Tanaman coontail merupakan tanaman air yang tumbuh terusmenerus, hidup berkoloni, dan dapat tumbuh di permukaan air hingga kedalaman 6,10 m. Tanaman coontail dapat tumbuh bercabangcabang. Percabangannya dapat menutupi seluruh permukaan air. Tanaman air ini dapat dijumpai di danau, kolam, sungai dengan kondisi air yang tercemar. Tanaman coontail bisa berkembang dengan baik sebagai agen fitoremediasi [9]. Bentuk tanaman coontail yang digunakan ditunjukkan pada Gambar 1. 


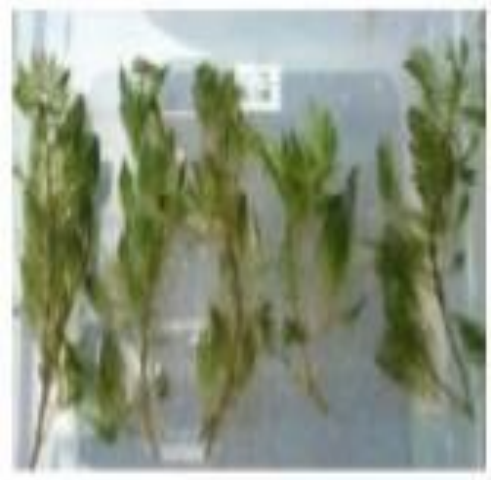

Gambar 1. Tanaman Coontail

Tanaman coontail dimasukkan ke dalam gelas kimia dan dibiarkan terapung dalam air. Hal ini disesuaikan dengan keadaan aslinya saat di sungai. Tanaman coontail terapung karena tidak memiliki akar sehingga tidak perlu ditancapkan dalam substrat. Oleh karena penanamannya cukup diikatkan ke media berupa batu atau kayu secara bergerombol dalam beberapa batang. Dalam penelitian ini tanaman dibiarkan terapung dengan sedikit terkait pada kawat. Tujuan corong gelas diletakkan dalam keadaan terbalik dan disangga dengan tiga kawat hingga corong gelas sedikit terangkat yaitu agar gelembung yang dihasilkan terperangkap dan dapat diamati dengan baik. Tabung reaksi yang digunakan juga harus terisi penuh dengan air agar ketika gelembung yang terperangkap di corong kaca naik ke bagian tabung reaksi, gelembung tersebut tidak pecah di tengah (Gambar 2). Penelitian ini dibuat tiga rangkaian dengan perlakuan yang berbeda.

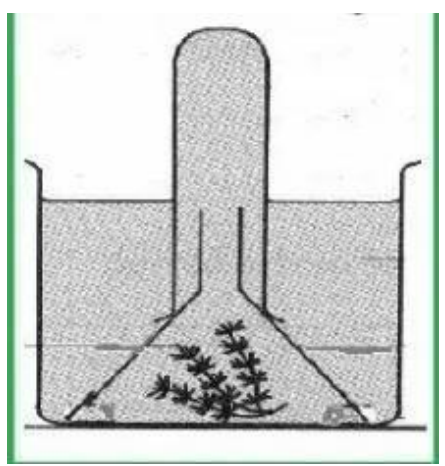

Gambar 2. Rangkaian alat percobaan Ingenhousez

Hasil penelitian menunjukkan saat corong gelas ditutup dengan tabung reaksi, gelembung udara bermunculan di sekitar tanaman coontail kemudian mengapung ke permukaan. Gelembung yang dihasilkan adalah gas oksigen yang terbentuk karena proses fotolisis ketika air diuraikan

$$
2 \mathrm{H}_{2} \mathrm{O} \longrightarrow 4 \mathrm{H}^{+}+\mathrm{O}_{2}
$$

menjadi gas oksigen dengan persamaan reaksi sebagai berikut:

\subsection{Percobaan satu: dengan cahaya}

Percobaan pertama diletakkan di tempat yang secara langsung terkena sinar matahari. Proses fotosintesis berjalan cepat karena di dalam air sebenarnya telah terdapat sejumlah karbon dioksida terlarut (meskipun dalam jumlah kecil) dan mendapat energi yang cukup untuk melakukan proses fotosintesis tersebut. Namun, jumlah gelembung yang terbentuk tidak sebanyak percobaan tiga. Hal ini disebabkan, walaupun keduanya memiliki energi untuk produksi yang melimpah tetapi jumlah bahan baku yang tersedia tidak sama. Grafik hubungan jumlah gelembung/satuan waktu pada cahaya matahari langsung ditunjukkan pada Gambar 3.

Berdasarkan Gambar 3 menunjukkan grafik perubahan jumlah gelembung atau gas oksigen pada cahaya matahari langsung. Saat sepuluh menit pertama muncul gelembung namun masih sedikit. Sepuluh menit kedua gelembung mulai bertambah. Pada sepuluh menit ketiga dan sepuluh menit keempat gelembung menjadi sangat banyak. Hal tersebut dikarenakan semakin tinggi intensitas cahaya maka semakin banyak ATP yang terbentuk, sehingga mempercepat fotosintesis. Maka gelembung yang dihasilkan semakin banyak.

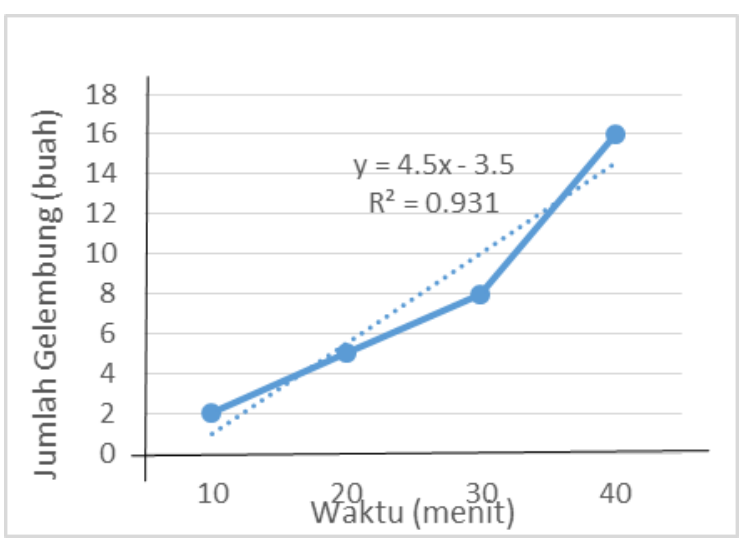

Gambar 3. Grafik hubungan jumlah gelembung per satuan waktu pada cahaya matahari langsung

Laju fotosintesis dipengaruhi oleh intensitas cahaya matahari karena proses fotosintesis hanya akan terjadi jika ada cahaya dan melalui perantara pigmen hijau klorofil yang terletak pada organel sitoplasma yaitu kloroplas. Sebagian energi matahari yang di serap akan di ubah menjadi 
energi kimia, yaitu berupa zat kimia berenergi tinggi. Selanjutnya, zat itu akan digunakan untuk proses penyusun zat gula. Sebagian energi matahari juga digunakan untuk fotolisis air $\left(\mathrm{H}_{2} \mathrm{O}\right)$ sehingga dihasilkan ion hidrogen $\left(\mathrm{H}^{+}\right)$dan $\mathrm{O}_{2}$. Ion hidrogen tersebut akan digabungkan dengan $\mathrm{CO}_{2}$ membentuk zat gula $\left(\mathrm{CH}_{2} \mathrm{O}\right)_{n}$, sedangkan $\mathrm{O}_{2}$ nya akan dikeluarkan berupa gelembung. Klorofil dan beberapa pigmen lain seperti $\beta$-karoten yang terorganisir dalam kelompok-kelompok di membran tilakoid dan terlibat dalam reaksi terang. Masing-masing pigmen yang warnanya berbedabeda dapat menyerap warna cahaya berbeda dan melepaskan energinya kepada molekul klorofil pusat untuk melakukan fotosintesis. Klorofil a, klorofil b, dan karotenoid membentuk suatu kumpulan sebagai "pengumpul cahaya" yang disebut kompleks antena. Sebelum sampai ke pusat reaksi, energi dari partikel cahaya (foton) akan dipindahkan dari satu molekul pigmen ke molekul pigmen yang lain. Pusat reaksi merupakan molekul klorofil pada fotosistem, yang berfungsi sebagai tempat terjadinya reaksi kimiawi (reaksi cahaya) fotosintesis pertama kalinya. Reaksi fotosintesis ditulis dengan persamaan reaksi berikut [10]:

$$
\mathrm{CO}_{2}+\mathrm{H}_{2} \mathrm{O} \stackrel{\text { Energi cahaya }}{\longrightarrow}\left(\mathrm{CH}_{2} \mathrm{O}\right)_{\mathrm{n}}+\mathrm{O}_{2}
$$

\subsection{Percobaan kedua: tanpa cahaya}

Percobaan kedua diletakkan di dalam ruangan. Ketika intensitas cahaya rendah, perputaran gas pada fotosintesis lebih kecil daripada respirasi. Pada keadaan di atas titik kompensasi yaitu konsentrasi karbon dioksida yang diambil untuk fotosintesis dan dikeluarkan untuk respirasi seimbang, maka peningkatan intensitas cahaya menyebabkan kenaikan sebanding dengan laju fotosintesis.

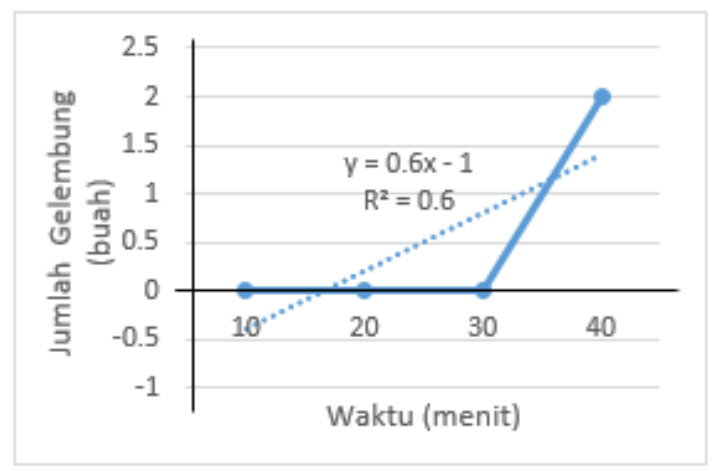

Gambar 4. Grafik jumlah gelembung per satuan waktu di ruangan tertutup
Pada intensitas cahaya sedang peningkatan laju fotosintesis menurun sedangkan pada intensitas cahaya tinggi laju fotosintesis menjadi konstan [10]. Grafik hubungan jumlah gelembung per satuan waktu pada cahaya matahari yang redup ditunjukkan pada Gambar 4.

Berdasarkan Gambar 4 grafik perubahan jumlah gelembung atau gas oksigen pada ruang tertutup. Pada sepuluh menit pertama tidak terdapat gelembung, sepuluh menit kedua masih belum terdapat gelembung, menit ke-30 tidak muncul gelembung dan pada sepuluh menit keempat mulai muncul gelembung namun sangat sedikit. Peristiwa ini terjadi karena tanaman coontail tidak dapat melakukan proses fotosintesis dengan sempurna di tempat yang teduh sehingga tidak dapat menghasilkan jumlah gelembung yang banyak, gelembung tersebut adalah merupakan gas oksigen. Hal ini terjadi karena walaupun di dalam air terdapat $\mathrm{CO}_{2}$ terlarut tetapi energi yang tersedia (cahaya) untuk melakukan proses fotosintesis oleh coontail sangat sedikit, maka tidak akan terbentuk hasil fotosintesis. Karena, semakin rendah intensitas cahaya, semakin rendah pula ATP (energi) yang terbentuk, sehingga memperlambat laju reaksi fotosintesis.

\subsection{Percobaan ketiga: dengan air hangat dan tanpa cahaya}

Percobaan ketiga menggunakan air hangat sebagai peningkatan suhu. Dalam percobaan yang dilakukan, air yang diisikan ke dalam tabung reaksi tidak terisi penuh karena airnya yang panas. Suhu merupakan salah satu faktor lingkungan yang dapat mempengaruhi fotosintesis, karena aktivitas fotosintesis sensitif terhadap tekanan yang disebabkan oleh suhu [11]. Air yang digunakan sebelumnya dipanaskan terlebih dahulu hingga suhu $40-50{ }^{\circ} \mathrm{C}$. Dipanaskan hingga suhu 40-50 ${ }^{\circ} \mathrm{C}$, suhu tersebut adalah merupakan suhu optimum tanaman atau tumbuhan dapat melakukan fotosintesis ketika cahaya matahari yang diterimanya kurang, sehingga tanaman tetap dapat melakukan proses fotosintesis maksimal. Jika suhu air yang digunakan adalah suhu kamar atau di bawah $40-50{ }^{\circ} \mathrm{C}$ tanpa bantuan cahaya matahari maka tanaman kurang maksimal melakukan fotosintesis, sebaliknya jika suhu air yang digunakan di atas $40-50{ }^{\circ} \mathrm{C}$ maka tanaman tersebut akan layu bahkan mati, karena pada suhu tinggi karbon dioksida kurang larut dalam air dan kloroplas sehingga menurunkan laju fotosintesis. Hal ini terjadi karena ada cekaman kekeringan dan penutupan stomata sehingga menghambat 
fotosintesis juga menyebabkan kerusakan sementara atau permanen protoplasma yang mengakibatkan menurunnya kecepatan fotosintesis, semakin tinggi suhu semakin cepat penurunan laju fotosintesis [10]. Oleh karenanya dibutuhkan suhu yang optimal. Suhu optimal berpengaruh pada hidrolisis air dan difusi karbon dioksida ke dalam daun, tetapi akan sangat berpengaruh terhadap reaksi- reaksi biokimia fiksasi dan reduksi karbon dioksida. Oleh sebab itu, peningkatan suhu akan menurunkan laju fotosintesis sampai terjadinya denaturasi enzim dan kerusakan pada fotosistem. Grafik hubungan jumlah gelembung per satuan waktu pada peningkatan suhu ditunjukkan pada Gambar 5.

Berdasarkan Gambar 5 menunjukkan grafik perubahan jumlah gelembung atau gas oksigen pada ruang tertutup. Pada sepuluh menit pertama gelembung yang dihasilkan cukup banyak begitu juga dengan sepuluh menit berikutnya. Hal ini dikarenakan dengan adanya peningkatan suhu maka energi atau ATP yang dihasilkan pun lebih tinggi. Karena dengan peningkatan energi maka akan semakin mudah tanaman tersebut melakukan fotosintesis. Kenaikan suhu menyebabkan pergerakan molekul-molekul yang bereaksi semakin bertambah. Reaksi tersebut pada hakikatnya dipercepat oleh enzim. Dengan kenaikan suhu, peningkatan rangsangan molekul akan merusak struktur tersier yang diikuti dengan penurunan aktivitas enzim dan laju reaksi.

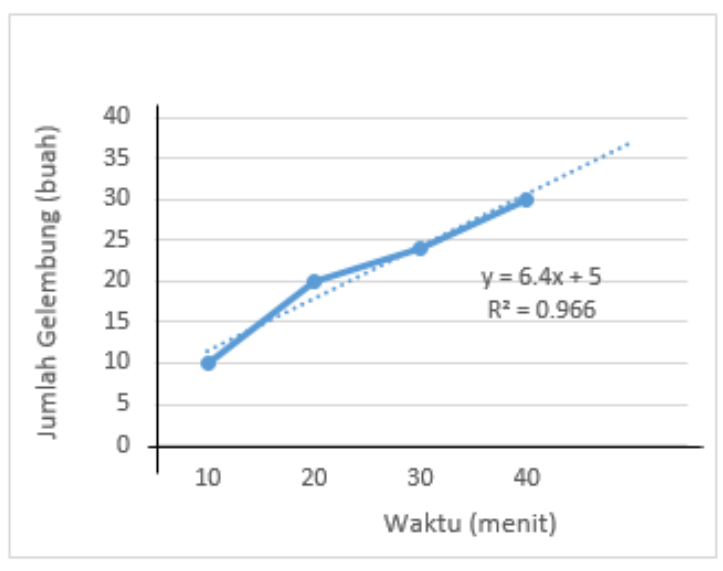

Gambar 5. Grafik jumlah gelembung/satuan waktu dengan menggunakan air hangat.

Tanaman coontail baik digunakan sebagai agen fitoremediasi karena tanaman ini memiliki kemampuan berfotosintesis yang cukup baik untuk menjaga kelangsungan hidup biota sungai, danau maupun kolam meski dalam keadaan tercemar, intensitas cahaya matahari yang rendah dan suhu yang cukup tinggi tanaman ini masih menghasilkan oksigen dengan baik tanpa penambahan zat kimia lain sebagai katalisator. Metode yang digunakan dalam penelitian ini sesuai dengan tujuan penelitian untuk mengetahui kemampuan tanaman coontail dalam memproduksi oksigen dengan beberapa faktor yang mempengaruhinya. Metode penelitian ini dapat dimutakhirkan dan dikembangkan dengan membuat pemrograman dengan teknologi Structured Query Language (SQL) untuk pembuatan kecerdasan buatan yang disambungkan dengan rangkaian percobaan Ingenhousz, sehingga meningkatkan kemampuan, ketepatan, akurasi dengan penggunaan jenis parameter yang lebih beragam [12].

\section{Kesimpulan}

Berdasarkan hasil penelitian dan pembahasan yang telah dilakukan maka dapat disimpulkan bahwa proses fotosintesis menghasilkan oksigen yang dipengaruhi oleh suhu dan intensitas cahaya. Tanaman coontail baik digunakan sebagai agen fitoremediasi karena tanaman ini memiliki kemampuan berfotosintesis yang cukup baik untuk menjaga kelangsungan hidup biota air.

\section{Daftar Pustaka}

[1] Yudo S. Kondisi Pencemaran Logam Berat di Perairan Sungai DKI Jakarta. J Air Indones. 2006. 2(1):1-13.

[2] Ulli Kadaria Sia. Uji Tanaman Coontail (Ceratophyllum demersum) Sebagai Agen Fitoremediasi Limbah Cair Kopi. J Teknol Lingkung Lahan Basah. 2017. 5(1). http://dx.doi.org/10.26418/jtllb.v5i1.18541

[3] Tarigan Z, . E, Rozak A. Kandungan Logam Berat $\mathrm{Pb}, \mathrm{Cd}, \mathrm{Cu}, \mathrm{Zn}$ dan Ni dalam Air Laut dan Sedimen di Muara Sungai Membramo, Papua dalam Kaitannya dengan Kepentingan Budidaya Perikanan. Makara Sci Ser. 2010. 7(3). http://dx.doi.org/10.7454/mss.v7i3.368

[4] Anshar AM. Study of Methylene Blue and Eosin in Adsorption Humin. Universitas Gadjah Mada; 2016.

[5] Qadeera R, Rehan AH. Study of The Adsorption of Phenol by Activated Carbon from aqueous solutions. Turkish J Chem. 2002. 26:357-61.

[6] Handoko P, Fajariyanti Y. Pengaruh spektrum cahaya tampak terhadap laju fotosintesis tanaman air Hydrilla verticillata. In: Seminar Nasional X Pendidikan Biologi FKP UNS. Surabaya; 2008. hal. 1-9.

[7] Syah YM, Hakim EH, Makmur L, Kurdi VA, 
Ghisalberti EL, Aimi N, et al. Prenylated 2Arylbenzofurans from Two Species of Artocarpus. Nat Prod Commun. 2006. 1(7): 549-552.

https://doi.org/10.1177/1934578x0600100706

[8] Kusumaningtyas, V. A., Syah, Y. M., Juliawaty DL. Two stilbenes from Indonesian Cassia grandis and their antibacterial activities. Res J Chem Environ. 2020. 24(1):61-63.

https://worldresearchersassociations.com/Archiv es/RJCE/Vol(24)2020/January2020.aspx

[9] Wahjuni NS, Anggara D, Rinjayanti D. Comparison of adsorption level from chitin and activated carbon to absorb the chromium in stirred tank. Ekuilibrium. 2005. 4(2):1-10.

[10] Proctor J, Loveless AR. Principles of Plant Biology for the Tropics. J Appl Ecol. 1984. 21(2):723.http://dx.doi.org/10.2307/2403447
[11] Ribeiro GF, Côrte-Real M, Johansson B. Characterization of DNA damage in yeast apoptosis induced by hydrogen peroxide, acetic acid, and hyperosmotic shock. Mol Biol Cell. 2006/08/09. 2006. 17(10):458491.

https://pubmed.ncbi.nlm.nih.gov/16899507

[12] Melina, Putra EK, Witanti W, Sukrido, Kusumaningtyas VA. Design and Implementation of Multi Knowledge Base Expert System Using the SQL Inference Mechanism for Herbal Medicine.

J Phys Conf Ser. $\quad 2020 . \quad 1477(2): \quad 1-9$ https://doi.org/10.1088/1742$\underline{6596 / 1477 / 2 / 022007}$ 